\title{
Innovation Processes: Do They Help or Hinder New Product Development Outcomes in Irish SMEs?
}

Research Article

\author{
Peter Robbins ${ }^{1 *}$ and Colm O'Gorman² \\ ${ }^{1}$ Lecturer in Innovation \& Entrepreneurship, Maynooth University \\ \& Founder and Director of the Innovation Foundation \\ (www.innovationfoundation.ie) Rowan House, North Campus, Maynooth, \\ County Kildare \\ ${ }^{2}$ DCU Business School, Dublin City University
}

\begin{abstract}
Small- and medium-sized enterprises (SMES) make a considerable contribution to the development and diffusion of innovation as well as accounting for the bulk of economic activity and employment in Ireland. A formal process for managing the stages of innovation projects is generally cited as a key component of best practice in new product development (NPD). Successfully managing innovation is an important business objective for SMEs, and yet, relatively little is known about how innovation-active firms approach innovation and, specifically, whether firms use formal processes to manage their NPD activities. This study of innovation-active Irish SMEs finds that three quarters of firms report that they do not operate a formal innovation process, yet this is not associated with poorer performance in terms of revenues from new products and services; and there are few differences between firms with formal innovation processes and firms with informal innovation process across each stage of the Innovation Value Chain. Having a more formal innovation process is, however, associated with success at bringing novel products to market. This study contributes to our understanding of the management of innovation in SMEs and to the emerging literature on SMEs that has emphasised both the prevalence and the effectiveness of informal management processes.
\end{abstract}

Keywords: innovation $\bullet$ innovation audit $\bullet$ Ireland $\bullet I V C \cdot N P D \cdot S M E$

(C) De Gruyter Open Sp. z o.0.

\section{Introduction}

Innovation is fundamental to the survival and growth of firms, and ultimately to the health of national economies (Ganotakis and Love, 2012). Small and medium-sized enterprises (SMEs) and entrepreneurs are crucial for identifying new avenues to more sustainable and inclusive growth, because of their twin roles in creating and diffusing innovation and providing employment (OECD, 2014).

The ability to innovate effectively is increasingly viewed as the single most important factor in developing and sustaining competitive advantage (Tidd and Bessant, 2009), with new product development (NPD) 'among the essential processes for success, survival and renewal of organisations' (Brown and Eisenhardt, 1995: 344). The NPD process is arguably the most important dynamic capability within a firm (Nelson and Winter, 1982); and NPD programmes can be the most profitable growth strategy when compared to mergers, alliances, acquisitions, or joint ventures (Jones et al., 2012).

The rationale for studying innovation in SMEs is clear. First, SMEs are important players in the national innovation ecosystem, even if only because they are so numerous and account for the bulk of economic activity in most economies (Veugelers, 2008). In 2007, SMEs accounted for $99 \%$ of enterprises in the European Union, estimated to be 20 million separate businesses, and they provided two-thirds of employment (Audretsch et al., 2009). Similarly, in Ireland, SMEs make up a substantial proportion of the enterprise economy, with more than $99 \%$ of businesses in this sector and $69 \%$ of people employed by them. Despite this, SMEs account for only $46 \%$ of gross value added (Central Statistics Office, 2013). In Europe, SMEs have lower labour productivity than large 
enterprises. Hence they 'contribute a considerably lower share to value added (58\%) than to employment (67\%)' (Audretsch et al., 2009: 5).

Second, in Ireland, the context for this study, there is a strong policy focus on innovation, with policy makers arguing that success at innovation is critical to industrial development and national competitiveness: 'innovation in all its dimensions will continue as the central driver of wealth creation, economic progress and prosperity in the coming decades' (Forfás, 2009: 6). The policy focus is both on Irish-owned firms and the subsidiaries of foreign-owned multinational corporations (MNCs). Veugelers (2008) noted that international firms are engaging in collaboration and external sourcing of technologies, with SMEs as one such source. Consequently, countries without a vibrant SME base will be less attractive to large, innovative and increasingly mobile businesses.

Comparing Ireland to the 26 other European countries, the EU Innovation Union Scorecard (IUS) ranks Ireland as ninth highest in terms of innovation performance, in the group they refer to as Innovation Followers (European Union, 2014). However, extant research from the Community Innovation Survey (Forfás, 2012) suggests that many firms in Ireland are not innovation-active, that smaller firms are less innovative than larger firms and that subsidiaries of foreign-owned multi-national corporations are more innovative than Irish-owned firms.

In Ireland over $40 \%$ of firms are not innovation active, in that they have not 'engaged in any innovation activities' over the past two years (Forfás, 2012: 6). The firms that are actively involved in NPD have a disproportionately high turnover (78\% of the total) and they also employ more people (77\%). Over one in four (28\%) enterprises had product innovations, whilst a third (33\%) was engaged in process innovations. The CIS data suggests that larger firms are almost twice as likely to be active in innovation. This suggests that current innovation policies and supports are more adequately addressing the requirements of larger firms rather than SMEs (Healy et al., 2014).

In Ireland, there is a link between foreign ownership and innovation, with foreign-owned firms more likely to be innovative than Irish-owned firms in both the area of product innovation (Harris and Trainor, 1995; Love et al., 1996) and their adoption of new processes and technologies (Hewitt-Dundas, 2006). The CIS survey reports that Irish-owned firms are less likely than the foreign-owned firms located in Ireland to be engaged in innovation of any type (product, service, process, marketing and organisational). Furthermore, Irish-owned firms are less likely than foreign-owned firms to launch a product or service that is new to the market, as the innovations of Irish firms are more likely to be merely 'new to the firm'.

Ireland's relatively high ranking in the innovation table is partially attributable to the presence of subsidiaries of MNCs in Ireland that, according to the EU Innovation Scorecard study (2014), contribute disproportionally to innovation activity in Ireland. The dominance of foreign-owned firms is significant with, for example, only two Irishowned firms appearing in the list of Ireland's top 20 electronics companies and only $2 \%$ of patent applications made in Ireland being made by Irish residents (Tyng-Ruu Lin et al., 2010).

Despite its importance, relatively little is known about how firms in Ireland manage innovation (Hewitt-Dundas and Roper, 2008). The existing knowledge base includes a series of quantitative studies (e.g. Geroski et al., 1997; Malerba and Orsenigo, 1997; Cefis, 2003; McAdam et al., 2004; Jordan and O'Leary, 2011; Doran et al., 2012). Extant research that studies the link between product innovation and profitability shows that innovating firms are persistently more profitable than non-innovators (Geroski et al., 1997; Cefis and Ciccarelli, 2005). Roper and HewittDundas (2008) suggested that this is because multiple innovations may provide cumulative high profits even though the chances of success of any individual innovation may be relatively low and its profits transitory.

The CIS data provides answers to some 'what' questions, such as what size of firm is more likely to be involved in various types of innovation; and what type of innovation is more prevalent in a given sector; but it does not answer the 'how' questions which might help elucidate how successful firms organise for innovation. This paper addresses this knowledge gap by exploring whether there is any benefit to Irish owned SMEs of adopting a formal innovation process.

The paper is structured as follows. First, the literature on innovation processes and managing the innovation process across Hansen and Birkinshaw's innovation value chain (IVC) (2007) is reviewed. Then, the research method is outlined. To gather data on Irish-owned SMEs, an online innovation audit tool was developed by the lead author. The tool was developed as part of this study and provided firms with the opportunity to self-assess their innovation capabilities and practices. The innovation audit tool reflects the stages of the IVC. The findings section explores the extent and impact of formal processes in the management of innovation. The paper concludes by discussing the findings and outlining implications for practice. 


\section{Literature review}

\section{Managing the innovation process}

Innovation is the generation, acceptance and implementation of new ideas, processes, products or services (Thompson, 1965). Drucker (1985) defined innovation as the specific instrument of entrepreneurship and the act that endows resources with a new capacity to create wealth; while Chandler et al. (1998) asserted that innovation is not just a novel idea, it's a process that includes developing the idea into a usable product or service to gain a competitive advantage in the marketplace. Bessant et al. suggested that 'innovation represents the core renewal process in any organisation. Unless it changes what it offers the world, and the way in which it creates and delivers those offerings it risks its survival and growth prospects' (2005: 1366).

Since Schumpeter's (1939) seminal work, many researchers have attempted to interpret the phenomenon of innovation and how it can best be managed to deliver growth (Brophey et al., 2013). SMEs contribute significantly to economic growth (Audretsch et al., 2009), and product innovation is a key driver of the economic performance and growth of small firms (Rosenbusch et al., 2011). The importance of innovation for SMEs and start-up firms was argued by Lee et al. (2001) who pointed out that due to resource shortcomings, scale diseconomies and questionable reputation, innovation needs to be a key differentiator for SMEs. While small firms may have more agility and flexibility than larger ones, their resources and skills are more limited and they lack the organisational and marketing skills of large firms (Van de Vrande et al., 2009). These factors create specific challenges for SMEs in managing NPD and innovation efforts (Berends et al., 2014). However, on the positive side, Tomlinson observed that as innovation becomes more risky for large firms, 'a trend had emerged to subcontract it out through (largely SME) supply chains, which often benefitted from good links with regulators and state funded bodies' (2011: 95).

SMEs make a key contribution to the economy in terms of employment, innovation and growth (Turner et al., 2010). Kenny and Reedy (2006), in their study of Irish SMEs reported a significant correlation between commitment to research and development (R\&D) and the number of new products and services launched. They further found that 'management' and the 'managing director' were the two primary sources for new ideas in the firms surveyed. Given the link between product innovation performance and firm performance, Cormican and O'Sullivan (2004) argued that managers should seek to ensure that the innovation process is managed. However, for many firms, particularly smaller firms, managers are often unaware of prior research that provides a large body of knowledge on 'good practice'. Many firms do not know of these practices and their association with successful NPD (Barclay and Porter, 2005). Existing case study evidence suggests that projects are often ad hoc and iterative, rather than planned and linear (Hoffman et al., 1998; March-Chorda et al., 2002). In managing innovation, SMEs often encounter challenges arising specifically from limited management support for innovation where senior management prioritise 'pet' projects and assign resources to them, while other projects end up as 'orphans' and are starved of support (Owens, 2007). Meyer et al. (2005) suggested that the management of NPD projects is complex, involving the effective integration of people, organisational processes, ideas and plans. If there is a failure in any one of these elements, or if they are not well integrated, the NPD process becomes less effective.

Having a dedicated, customised innovation process has frequently been cited as a defining factor between the success and failure of NPD projects (Brown and Eisenhardt, 1995; Griffin, 1997; Page, 1993). Extant literature suggests that organisations that have a dedicated innovation process experience high levels of success in innovating (Kahn et al., 2006; Cooper and Edgett, 2008). Best practice characteristics include the use of a formal NPD process that is documented and focuses effort on quality of execution, but the process should also be flexible and adaptable to meet the specific needs of individual projects. Poor practices are characterised by the absences of formal stages in projects and a lack of paperwork or process to guide various projects (Kahn et al., 2012).

Yet, other research suggests that formality in the innovation process may in fact reduce the flow of radical and novel innovations. This perspective, outlined by Hutchins and Muller, suggests that most innovation management processes are built around a 'typical' project and, hence, the process often becomes:

hostile to unorthodox opportunities that don't fit neatly inside. Over time, the organisation develops a prejudice against creative growth opportunities that, by their very nature, are often unconventional or ambiguous. Innovation is squeezed out of projects as they move through the pipeline in order to make them more palatable to internal constituencies or conform to traditional expectations (Hutchins and Muller, 2012: 31). 
Akroyd et al. (2009) referred to this as the 'Help or Hinder' debate in which one stream of research suggests that formal, innovation processes help NPD, while another stream considers it to hinder NPD efforts. The 'hinder' NPD innovation literature tends to either give a lower profile or ignore the use of innovation processes, such as stagegate during NPD innovation (e.g. Tushman, 1997; Amabile, 1998). The contention of the 'hinder' advocates is that a stage-gate approach (and some other innovation management models) is designed for stable, steady conditions and that it may be less useful in the contexts of rapid change and uncertainty, conditions that characterise many NPD environments.

In contrast, the 'help' stream of literature suggests that the use of innovation management processes has a positive effect on NPD innovation (e.g. Bart, 1991; Kahn et al., 2006, 2012; Barczac et al., 2009). This stream of research contends that formal innovation processes root innovation programmes in pragmatism and tend to eliminate elements ('excesses') and ideas that may seem unlikely to have market appeal. This argument is consistent with Cooper's (2001) and Bonner's (2005) contention that such processes are important for coordinating and controlling NPD innovation projects. Davila et al. (2009) suggested that management controls provide the infrastructure to anchor product innovation. Akroyd et al. (2009) suggested that the primary imperative in managing innovation projects is to reduce uncertainty (either market, business model or technical) to the point where conventional management practices are appropriate, or to where it becomes apparent that the project should be abandoned. Innovation management processes can help accomplish this.

For firms choosing to use a formal process, the dominant approach to managing innovation is the stage-gate approach (Cooper and Kleinschmidt, 2007). Stage-gate is a prescriptive and mechanistic approach to managing specific innovation projects that mandates a sequence of defined activities punctuated by key decision points. It is a linear model of innovation and it maps the flow of decisions at key stages of an innovation project. As such, it provides managers with a clear process for managing innovation. More recent perspectives on innovation argue that the innovation process involves a number of sub-processes and cannot be considered as just one skill, or just one act. Hansen and Birkinshaw (2007) proposed the notion of the IVC as a general framework within which almost all firms' innovation activities can be considered. As Yang states, 'firm innovation capability is a meta-capability' (2012: 38).

Many researchers view innovation projects in terms of three discrete stages. These stages are sufficiently distinct to require different skills to manage them effectively. O'Connor and Ayers (2005) advocated a three-part programme for innovation in which the three elements are discovery, incubation and acceleration. Such a three-part division of the innovation process is increasingly a feature of the literature (e.g. Cooper and Kleinschmidt, 1996; Veryzer, 1998; Tidd and Bodley, 2002; Vuola and Hameri, 2006; Hansen and Birkinshaw, 2007; Loewe and Chen, 2007; Roper et al., 2008; O'Connor, 2009) (Table 1). The three parts described are generally configured as: (i) the discovery or idea generation phase, (ii) the incubation or transformation phase and (iii) the launch or implementation phase.

Table 1. Phases in the innovation process

\begin{tabular}{cccc}
\hline Authors & Stage 1 & Stage 2 & Stage 3 \\
\hline \hline Roper et al. (2008) & Knowledge Sourcing & Transformation & Exploitation \\
Hansen and Birkinshaw (2007) & Idea Generation & Idea conversion & Idea diffusion \\
Loewe and Chen (2007) & Discovery & Opportunity & Realisation \\
O'Connor and Ayers (2005) & Discovery & Incubation & Acceleration \\
\hline
\end{tabular}

Hansen and Birkinshaw (2007) suggested that executives need to view the process of transforming ideas into commercial outputs as an integrated flow, from end-to-end, in what they refer to as the IVC (Table 2). The first of the three phases in the chain is idea generation, which can happen in three ways: within a single department, across the firm using cross-functional teams, or by involving external partners to generate ideas. The first phase is linked to organisational creativity. Any NPD process requires a high level of creative performance. Innovation inevitably involves creativity in that it involves the initiation, identification or discovery of something novel, an idea, technology or process that is new to the organisational setting, which is then followed by its development and implementation.

The second phase is to convert ideas, to incubate the best ones, and to amplify the elements of the ideas that have most appeal. More specifically, the second phase helps select, sift, rank and prioritise ideas for funding (or resourcing) aimed at developing them into products, services or practices. The third phase is to diffuse, exploit 
or implement those ideas both inside the organisation or outside in the case of launching new products and services or creating new markets.

Roper et al. (2008) developed a similar model in which an 'innovation event', like the launch of a new product, service or process, represents the end of a series of knowledge sourcing and translation activities by a firm. It also marks the start of a means of value creation that, subject to the firm's capabilities and the buoyancy of the markets it operates in, should yield an improvement in NPD results. According to Roper et al. (2008), the first link in the IVC is a firm's knowledge sourcing activity; these authors focus in particular on the factors that drive firms' engagement with particular knowledge sources, such as experts, research institutes, etc. The second link in the IVC is the process of knowledge transformation, in which knowledge sourced by the enterprise is translated into innovation outputs. The final link in the IVC is knowledge exploitation, i.e. the firms' ability to fully commercialise their innovations.

While Roper et al.'s (2008) model mirrors closely the Hansen and Birkinshaw (2007) IVC model, it does contain some specifics about how and, specifically, where firms can access knowledge that may be useful as a start point for new product or service ideas. Roper et al. (2008) suggested five sources of such knowledge: internal dedicated R\&D, backward linkages to suppliers and consultants, forward linkages to customers/consumers, horizontal linkages to competitors or joint ventures and public linkages to research institutes and universities.

Table 2. The Innovation Value Chain

\begin{tabular}{|c|c|c|c|c|c|c|}
\hline & \multicolumn{3}{|c|}{ Idea Generation } & \multicolumn{2}{|c|}{ Conversion } & \multirow{2}{*}{$\begin{array}{c}\text { Diffusion } \\
\text { Spread }\end{array}$} \\
\hline & In-House & $\begin{array}{l}\text { Cross- } \\
\text { Pollination }\end{array}$ & External & Selection & Development & \\
\hline & $\begin{array}{c}\text { Creation within } \\
\text { a unit }\end{array}$ & $\begin{array}{l}\text { Collaboration } \\
\text { across units }\end{array}$ & Collaboration & $\begin{array}{l}\text { Screening and } \\
\text { initial funding }\end{array}$ & $\begin{array}{l}\text { Movement from } \\
\text { idea to first result }\end{array}$ & $\begin{array}{l}\text { Dissemination } \\
\text { across the } \\
\text { organisation }\end{array}$ \\
\hline Key Questions & $\begin{array}{l}\text { Do people in } \\
\text { our unit create } \\
\text { good ideas on } \\
\text { their own? }\end{array}$ & $\begin{array}{l}\text { Do we create } \\
\text { good ideas by } \\
\text { working across } \\
\text { the company? }\end{array}$ & $\begin{array}{c}\text { Do we source } \\
\text { enough good } \\
\text { ideas from } \\
\text { outside the firm? }\end{array}$ & $\begin{array}{c}\text { Are we good at } \\
\text { screening and } \\
\text { funding new } \\
\text { ideas? }\end{array}$ & $\begin{array}{l}\text { Are we good at } \\
\text { turning ideas into } \\
\text { viable products, } \\
\text { businesses and } \\
\text { best practice? }\end{array}$ & $\begin{array}{l}\text { Are we good } \\
\text { at diffusing } \\
\text { developed } \\
\text { ideas across the } \\
\text { company? }\end{array}$ \\
\hline $\begin{array}{l}\text { Key } \\
\text { Performance } \\
\text { Indicators }\end{array}$ & $\begin{array}{c}\text { Number of } \\
\text { high-quality } \\
\text { ideas generated } \\
\text { within a unit }\end{array}$ & $\begin{array}{c}\text { Number of high- } \\
\text { quality ideas } \\
\text { generated across } \\
\text { units }\end{array}$ & $\begin{array}{l}\text { Number of high- } \\
\text { quality ideas } \\
\text { generated from } \\
\text { outside the firm }\end{array}$ & $\begin{array}{l}\text { Percentage of all } \\
\text { ideas generated } \\
\text { that end up being } \\
\text { selected and } \\
\text { funded }\end{array}$ & $\begin{array}{l}\text { Percentage of } \\
\text { funded ideas that } \\
\text { lead to revenues; } \\
\text { number of months } \\
\text { to first sale }\end{array}$ & $\begin{array}{c}\text { Percentage of } \\
\text { penetration in } \\
\text { desired markets, } \\
\text { channels, } \\
\text { customer groups: } \\
\text { number of months } \\
\text { to full diffusion }\end{array}$ \\
\hline
\end{tabular}

Source: Hansen and Birkinshaw (2007)

\section{Research hypotheses}

We, therefore, expect that a formal innovation process will be associated with superior innovation performance in SMEs. We explore this in terms of the percentage of revenues from new products and services, and in terms of the novelty of new products and services. The IVC is increasingly being used as a rubric to examine firms' strengths and weaknesses in delivering an end-to-end NPD project. As the innovation process differs across the different stages of the IVC, we expect that the benefits of a formal process might vary by stage of the IVC. For example, as innovation, by definition, requires a break from routine, challenging the future, out-of-the-box thinking, risk taking and a step into the unknown (Burns and Stalker, 1961; Kanter, 1983; March, 1991), informality may be associated with better performance during the idea generation stage of the IVC; while formality may result in better performance as firms seek to move to the conversion and diffusion stages of the IVC. Formally, we expect:

Hypothesis 1: A formal process for managing innovation is associated with higher innovation performance (in terms of revenue generated through new products and services and, then novelty of new products and services).

Hypothesis 2: A formal process for managing innovation is associated with better performance at each stage of the IVC. 


\section{Research methodology}

\section{Data collection - the innovation audit tool}

To advance our understanding of how product innovation unfolds within innovation-active Irish-owned SMEs, an online audit tool based on the IVC was developed by the lead author. Innovation audits are used by firms to measure, benchmark and understand innovation performance (Chiesa et al., 1996; Cormican and O'Sullivan, 2004; Radnor and Noke, 2006). The usefulness of such tools is not merely in their capacity to develop a measure of firmlevel performance but also in their ability to assess the gap between best practice and actual practice, or between current performance and desired performance. A number of tools have been developed to measure firm capability at innovation (e.g. Sawhney et al.'s (2006) innovation radar, Radnor and Noke's (2006) innovation compass, Kahn et al.'s (2012) 'best practice survey').

The IVC can be used as an innovation audit tool, as it highlights strengths and weaknesses in firms' innovation performance (Ganotakis and Love, 2012). The survey instrument used in this study, called the Irish Innovation Index, is largely based on the IVC audit questions suggested by Hansen and Birkinshaw (2007) and was developed by the lead author to specifically gather data for this study. Basing the audit around the IVC means that it takes account of the different skills and activities that characterise the three phases of an innovation project or programme. The questions used to measure performance across each stage of the IVC were developed from the measures suggested by Hansen and Birkinshaw (2007) (Table 2).

By using this audit tool, we used a convenience sampling approach. The Irish Innovation Index audit tool was formally launched during national Innovation Week in Ireland, in November 2010. The announcement garnered considerable publicity in the national media and on the online business pages. The tool remained live for a period of 31 months (November 2010 to June 2014). Over this time, 596 self-audits were undertaken. Of the 596 self-audits, we include only firms that self-report they are innovation active (i.e. they have introduced a new or significantly improved product or service within the last three years), are Irish-owned, have less than 250 employees and which reported whether or not they had a formal innovation process. This resulted in 173 usable completed audits. It is important to note that the Irish Innovation Index attracted firms that were innovative active. The mean duration of time taken to complete the survey was 21 minutes. Of the 173 firms, $44 \%$ are micro (employing less than 10), 39\% are small (employing between 10 and 49) and 17\% medium sized (employing between 50 and 249). The firms are also classified in terms of whether their revenues come from services or product. Half of the firms report that their revenues are from selling services.

\section{Variables and analysis}

Table 3 summarises the responses to the innovation survey. The nature of a firms approach to innovation was measured in terms of a binary response to the question: 'Does your organisation have a formal innovation process: a structure and process for making innovation happen?' 23\% of firms responded that they had a formal innovation process. Firms with formal innovation processes manage their innovation processes differently in that these firms were also characterised by a number of other practices associated with innovation. Of all firms with a formal innovation process, $79 \%$ reported that they had an innovation strategy, $72 \%$ reported using formal metrics for the management of innovation projects, $67 \%$ reported using a dedicated team leader in innovation projects, $59 \%$ reported that they had an R\&D budget and $83 \%$ reported using teams to manage innovation. In contrast, for firms without a formal innovation process, only $10 \%$ reported that they had an innovation strategy, $17 \%$ reported using formal metrics, $13 \%$ reported having a dedicated team leader, $16 \%$ reported that they have an R\&D budget, and $55 \%$ use teams to manage innovation. The differences between firms with a formal innovation process and informal innovation process are statistically significant for innovation strategy $(p=0.000)$, formal metrics $(p=0.000)$, dedicated team leader $(p=0.000)$, formal R\&D budget $(p=0.000)$ and using teams $(p=0.001)$.

Two measures of overall innovation performance were included in the innovation audit tool. The first measured innovation outputs in terms of the percentage of sales revenues that came from products and services introduced within the past three years. The average across the firms was $38 \%$. The second overall measure of performance was based on a binary response to the question: 'Were your new product or service innovations the first of their kind to the market?' $31 \%$ of firms responded positively.

The performance of firms at each stage of the IVC was measured using a five-point Likert scale (strongly agree, agree, neither, disagree, strongly disagree). For the purposes of the analysis, this was reduced to a three-point 
scale by combining the 'strongly agree' and 'agree' responses and the 'disagree' and 'strongly disagree' responses. The mean response to each question used to measure performance across each stage of the IVC is listed in Table 3. The analysis compares firms with formal innovation process to firms without a formal innovation process. The two groups of firm are compared using cross tabulations and Pearson's chi-square tests.

There are a number of limitations associated with the use of an online innovation tool to gather data on firm innovation. As this study was carried out using a convenience sampling technique in which participants self-selected, the sample is not representative of all Irish firms or of all innovative Irish firms and, therefore, cannot be generalised beyond the respondent firms. A second limitation is that this firm-level data is based on a single respondent taking the survey on behalf of their firm.

Table 3. Descriptive statistics for product innovation - active firms

\begin{tabular}{|c|c|c|c|c|c|}
\hline Variable & $\mathbf{N}$ & Mean & SD & Min & Max \\
\hline Formal innovation process (0: No; 1 : Yes) & 173 & 0.23 & 0.419 & 0 & 1 \\
\hline Size (0: Micro and Small; 1: Medium) & 173 & 0.17 & 0.375 & 0 & 1 \\
\hline Sector (0: Other; 1: Services) & 173 & 0.50 & 0.501 & 0 & 1 \\
\hline \multicolumn{6}{|l|}{ Innovation performance } \\
\hline$\%$ revenue from new products and services & 173 & 37.7 & 28.8 & 0 & 100 \\
\hline $\begin{array}{l}\text { Were your new product or service innovations the first of their kind to the } \\
\text { market? (0: No; 1: Yes) }\end{array}$ & 142 & 0.31 & 0.464 & 0 & 1 \\
\hline \multicolumn{6}{|l|}{ Idea generation stage } \\
\hline \multicolumn{6}{|l|}{ In-house idea generation } \\
\hline Our culture makes it hard for people to put forward good ideas & 171 & 1.57 & 0.796 & 1 & 3 \\
\hline People in our unit come up with lots of good ideas on their own & 171 & 2.40 & 0.801 & 1 & 3 \\
\hline \multicolumn{6}{|l|}{ Cross-pollination within business } \\
\hline Few of our projects involve team members from different units or subsidiaries & 171 & 2.18 & 0.836 & 1 & 3 \\
\hline $\begin{array}{l}\text { Typically, our people collaborate on projects internally, across units, businesses } \\
\text { or subsidiaries }\end{array}$ & 172 & 2.41 & 0.815 & 1 & 3 \\
\hline \multicolumn{6}{|l|}{ External sourcing of ideas } \\
\hline $\begin{array}{l}\text { Our people often exhibit a 'not invented here' attitude - ideas from outside are } \\
\text { not considered as valuable as those invented within }\end{array}$ & 171 & 2.41 & 0.795 & 1 & 3 \\
\hline $\begin{array}{l}\text { Lots of good ideas for new products and businesses come from outside the } \\
\text { company }\end{array}$ & 171 & 1.65 & 0.793 & 1 & 3 \\
\hline \multicolumn{6}{|l|}{ Conversion stage } \\
\hline \multicolumn{6}{|l|}{ Selection } \\
\hline $\begin{array}{l}\text { We have tough rules for investment in new projects making it hard to get ideas } \\
\text { funded in most cases }\end{array}$ & 171 & 2.19 & 0.835 & 1 & 3 \\
\hline We have a risk-taking attitude toward investing in novel ideas & 172 & 2.15 & 0.847 & 1 & 3 \\
\hline \multicolumn{6}{|l|}{ Development } \\
\hline New-product-development projects often don't finish on time & 169 & 1.63 & 0.784 & 1 & 3 \\
\hline Managers receive lots of support developing new ideas & 170 & 1.74 & 0.809 & 1 & 3 \\
\hline \multicolumn{6}{|l|}{ Diffusion stage } \\
\hline We're slow to roll out new products & 173 & 2.01 & 0.886 & 1 & 3 \\
\hline Competitors are slow to copy our product introductions & 173 & 2.18 & 0.745 & 1 & 3 \\
\hline $\begin{array}{l}\text { We don't penetrate all possible channels, customer groups, and regions with } \\
\text { new products }\end{array}$ & 173 & 1.59 & 0.792 & 1 & 3 \\
\hline
\end{tabular}

Scale: $1-3$, where (1) is strongly agree/ agree, (2) neither agree nor disagree and (3) disagree /strongly disagree. 


\section{Findings}

\section{Innovation practices and new product/service performance}

While all 173 firms were innovation active, only $23 \%$ of firms have a formal process to manage their innovation initiatives. We hypothesised that these firms would perform better at innovation. For firms with a formal process, $47 \%$ of revenues come from new products/services introduced within the past three years (Table 4). In contrast, for firms without a formal innovation process, $35 \%$ of revenues come from products/services introduced within the past three years $(p=0.029)$. This suggests that firms can achieve high levels of innovation irrespective of the formality of their innovation process. The difference between the two groups of firm is not statistically significant at the $p<0.01$ and, therefore, Hypothesis 1 is not supported.

As differences in innovation might be determined by the firm's size and type of activity (sector), Table 4 also reports the mean revenues from innovation for micro and small firms compared to medium-sized firms (39\% compared to $30.5 \%, p=0.138$ ), and for service firms compared to non-service firms (40\% compared to $35.5 \%$, $p=0.300)$. As the percentage of revenues from new products or services is different at the $p<0.5$ level, a univariate analysis of variance (ANOVA) using formality of innovation process, size (micro and small compared to medium sized) and sector (service compared to non-service) was used to check if the difference reported between firms with formal and informal innovation processes is explained by size or sector (Table 5). The results of this analysis suggest that there is a significant difference in revenues from new products/services for micro and small firms in the service sector ( $55 \%$ for firms with a formal innovation process compared to $38 \%$ for firms with an informal innovation process, $p=0.023)$.

Using an alternative measure of innovation, the novelty of new products/services, there is a difference between the two groups of firms. $56 \%$ of firms with a formal process reported that their new products/services are the first of their kind to market, compared to $24 \%$ of firms without a formal innovation process $(p=0.000)$ (Table 4). Being first to the market is a characteristic that transcends all three components of the IVC. It suggests a higher level of originality in idea generation, a more risk-taking attitude in prioritising projects, and a capacity to execute and get to the market before competitors. The differences between micro and small firms and medium-sized firms $(30 \%$ and $36 \%, p=0.556)$ and between service compared to non-service firms $(24 \%$ compared to $37 \%, p=0.085)$ are not significant.

Table 4. Comparison of firm outputs

\begin{tabular}{|c|c|c|c|}
\hline Variable & Mean (STD) & $\begin{array}{l}\text { Levene's test for equality } \\
\text { of variances F-value (p) }\end{array}$ & t-test \\
\hline \multicolumn{4}{|c|}{ Percentage of revenues from new products/services } \\
\hline \multicolumn{4}{|l|}{ Innovation process } \\
\hline Informal $(n=134)$ & $0.352(0.278)$ & $1.432(p=0.233)$ & $0.029^{*}$ \\
\hline Formal $(n=39)$ & $0.466(0.308)$ & & \\
\hline \multicolumn{4}{|l|}{ Size } \\
\hline Micro and small $(n=144)$ & $0.392(0.294)$ & $2.694(p=0.103)$ & 0.138 \\
\hline Medium $(n=29)$ & $0.305(0.248)$ & & \\
\hline \multicolumn{4}{|l|}{ Sector } \\
\hline Non-service $(n=87)$ & $0.355(0.278)$ & $1.997(p=0.159)$ & 0.300 \\
\hline \multirow[t]{2}{*}{ Services $(n=86)$} & $0.400(0.297)$ & & \\
\hline & \multicolumn{2}{|c|}{ Innovations the first of their kind to market } & \\
\hline \multicolumn{4}{|l|}{ Innovation process } \\
\hline Informal $(n=110)$ & $0.24(0.427)$ & $10.586(p=0.001)$ & $0.000 * \star \star$ \\
\hline Formal $(n=32)$ & $0.56(0.504)$ & & \\
\hline \multicolumn{4}{|l|}{ Size } \\
\hline Micro and small $(n=120)$ & $0.30(0.460)$ & $1.082(p=0.300)$ & 0.556 \\
\hline Medium $(n=22)$ & $0.36(0.492)$ & & \\
\hline \multicolumn{4}{|l|}{ Sector } \\
\hline Non-service $(n=75)$ & $0.37(0.487)$ & $12.125(p=0.001)$ & 0.085 \\
\hline Services $(n=67)$ & $(0.430)$ & & \\
\hline
\end{tabular}

${ }^{*} p<0.05,{ }^{* *} p<0.01,{ }^{* * *} p<0.001$ 
Table 5. Percentage of revenues from new products/services - univariate ANOVA

\begin{tabular}{|c|c|c|c|c|c|c|c|c|c|c|}
\hline \multicolumn{3}{|l|}{ Variable } & \multirow[t]{2}{*}{$\mathbf{N}$} & \multirow[t]{2}{*}{$\begin{array}{l}\text { Mean } \\
(\%)\end{array}$} & \multirow[t]{2}{*}{$\begin{array}{l}\text { Standard } \\
\text { error }\end{array}$} & \multirow[t]{2}{*}{$\begin{array}{c}\text { Mean } \\
\text { difference }\end{array}$} & \multirow[t]{2}{*}{$\begin{array}{l}\text { Standard } \\
\text { error }\end{array}$} & \multirow[t]{2}{*}{ p-value } & \multicolumn{2}{|c|}{$\begin{array}{l}\text { 95\% Confidence } \\
\text { interval for } \\
\text { difference }\end{array}$} \\
\hline Size & Sector & $\begin{array}{l}\text { Innovation } \\
\text { process }\end{array}$ & & & & & & & $\begin{array}{l}\text { Lower } \\
\text { bound }\end{array}$ & $\begin{array}{l}\text { Upper } \\
\text { bound }\end{array}$ \\
\hline \multirow{4}{*}{$\begin{array}{l}\text { Micro and } \\
\text { small }\end{array}$} & Non-service & Informal & 55 & 33.745 & 3.820 & -11.588 & 8.252 & 0.162 & -27.881 & 4.705 \\
\hline & & Formal & 15 & 45.333 & 7.315 & & & & & \\
\hline & Services & Informal & 55 & 37.545 & 3.820 & $-17.349^{*}$ & 7.539 & $0.023^{*}$ & -32.234 & -2.464 \\
\hline & & Formal & 19 & 54.895 & 6.499 & & & & & \\
\hline \multirow[t]{4}{*}{ Medium } & Non-service & Informal & 14 & 33.571 & 7.571 & 6.905 & 18.024 & 0.702 & -28.682 & 42.492 \\
\hline & & Formal & 3 & 26.667 & 16.356 & & & & & \\
\hline & Services & Informal & 10 & 32.000 & 8.959 & 25.000 & 21.944 & 0.256 & -18.328 & 68.328 \\
\hline & & Formal & 2 & 7.000 & 20.032 & & & & & \\
\hline
\end{tabular}

* $\mathrm{p}<0.05$

${ }^{a}$ Adjustment for multiple comparisons: least significant difference (equivalent to no adjustments)

\section{Formality of innovation process across the Innovation Value Chain}

Overall, the data suggests that there are few differences between firms with formal innovation processes and firms with informal innovation process across each stage of the IVC. Of 13 measures across the IVC, there are only statistically significant differences $($ at $p<0.01)$ for three of the measures. Two of these measures are at the conversion stage (two of the four measures at the conversion stage) and one is at the diffusion stage (one of the three measures at the diffusion stage). Therefore, Hypothesis 2 is not supported.

Idea generation. The IVC suggests that six factors are important during the idea generation stage of the IVC. These relate to a firm's in-house idea generation, to cross-pollination within the business and external sourcing of ideas. It was expected that a formal innovation process might be associated with better performance on each of these activities. The data suggests that firms with formal innovation processes do not perform differently on any of these measures (at $p<0.01$ ) (Table 6).

In terms of idea generation, firms with a formal innovation process report that their culture does not make it hard for staff to put forward a good idea ( $79 \%$ compared to $57 \%$ for firms without a formal innovation process, $p=0.043$ ). Both firms with and without a formal innovation process report that staff come up with good ideas (72\% compared to $57 \%, p=0.168$ ).

There are differences between the two groups in terms of cross-pollination of ideas within the business. $64 \%$ of firms with a formal innovation process disagree with the statement that few of the firm's innovation projects involve team members from other units, compared to $39 \%$ for firms with no formal innovation process $(p=0.022)$. Similarly, for firms with a formal innovation process, $77 \%$ respond that staff typically collaborate on projects across units, compared to $58 \%$ for firms without a formal innovation process $(p=0.048)$.

In terms of external sourcing of ideas, there are no differences between firms with and without a formal innovation process in terms of staff exhibiting a 'not invented here' attitude ( $8 \%$ compared to $23 \%, p=0.052$ ), or in terms of reporting that lots of ideas come from outside the firm $(63 \%$ and $52 \%, p=0.154)$.

Conversion stage. The IVC suggests that four factors are important to the conversion stage of the IVC. The two components of the conversion stage are selection and development. Again, it was expected that a formal innovation process would be associated with better performance on these activities. The data suggests that firms with formal innovation processes do not achieve better results on two of the four measures (Table 7).

In terms of the selection process, there were no differences with respect to firms having tough rules for investment in new projects, which makes it difficult to get ideas funded. However, there is a difference in terms of risk-taking attitudes. $67 \%$ of firms with a formal innovation process reported that they had a risk-taking attitude towards investing in novel ideas, while, in contrast, for firms without a formal innovation process, just $38 \%$ of firms responded that they had a risk-taking attitude $(p=0.006)$. 
The development process refers to whether new product development projects finish on time and whether managers receive lots of support in developing new ideas. In terms of finishing on time, there is no difference between firms with and without a formal innovation process. However, firms with formal innovation processes are also characterised by a positive response to the question of whether managers receive support in developing new ideas $(79 \%$ compared to $40 \%, p=0.000)$.

Table 6. Comparison of firms with formal and informal innovation processes - idea generation stage

\begin{tabular}{|c|c|c|c|c|c|}
\hline Variable & & $\begin{array}{l}\text { Formal innovation } \\
\text { process, } n=39 \\
\%\end{array}$ & $\begin{array}{l}\text { Informal innovation } \\
\text { process, } n=134 \\
\%\end{array}$ & $\begin{array}{l}\text { Pearson } \\
\text { chi-square } \\
\text { F-value }\end{array}$ & p-value \\
\hline \multicolumn{6}{|l|}{ In house idea generation } \\
\hline $\begin{array}{l}\text { Our culture makes it hard for people to put } \\
\text { forward good ideas }\end{array}$ & $\begin{array}{l}\mathrm{SA} / \mathrm{A} \\
- \\
\mathrm{D} / \mathrm{SD}\end{array}$ & $\begin{array}{c}13 \\
8 \\
79\end{array}$ & $\begin{array}{l}21 \\
22 \\
57\end{array}$ & 6.277 & $0.043^{*}$ \\
\hline $\begin{array}{l}\text { People in our unit come up with lots of good } \\
\text { ideas on their own }\end{array}$ & $\begin{array}{l}\mathrm{SA} / \mathrm{A} \\
- \\
\mathrm{D} / \mathrm{SD}\end{array}$ & $\begin{array}{l}72 \\
10 \\
18\end{array}$ & $\begin{array}{l}57 \\
23 \\
20\end{array}$ & 3.571 & 0.168 \\
\hline \multicolumn{6}{|l|}{ Cross pollination within business } \\
\hline $\begin{array}{l}\text { Few of our projects involve team members } \\
\text { from different units or subsidiaries }\end{array}$ & $\begin{array}{l}\mathrm{SA} / \mathrm{A} \\
- \\
\mathrm{D} / \mathrm{SD}\end{array}$ & $\begin{array}{l}21 \\
15 \\
64\end{array}$ & $\begin{array}{l}30 \\
31 \\
39\end{array}$ & 7.667 & $0.022^{*}$ \\
\hline $\begin{array}{l}\text { Typically, our people collaborate on projects } \\
\text { internally, across units, businesses, or } \\
\text { subsidiaries }\end{array}$ & $\begin{array}{l}\mathrm{SA} / \mathrm{A} \\
- \\
\mathrm{D} / \mathrm{SD}\end{array}$ & $\begin{array}{c}77 \\
5 \\
18\end{array}$ & $\begin{array}{l}58 \\
20 \\
22\end{array}$ & 6.087 & $0.048^{*}$ \\
\hline \multicolumn{6}{|l|}{ External sourcing of ideas } \\
\hline $\begin{array}{l}\text { Our people often exhibit a 'not invented here' } \\
\text { attitude - ideas from outside are not considered } \\
\text { as valuable as those invented within }\end{array}$ & $\begin{array}{l}\mathrm{SA} / \mathrm{A} \\
- \\
\mathrm{D} / \mathrm{SD}\end{array}$ & $\begin{array}{c}8 \\
16 \\
76\end{array}$ & $\begin{array}{l}23 \\
22 \\
55\end{array}$ & 5.912 & 0.052 \\
\hline $\begin{array}{l}\text { Lots of good ideas for new products and } \\
\text { businesses come from outside the company }\end{array}$ & $\begin{array}{l}\mathrm{SA} / \mathrm{A} \\
- \\
\mathrm{D} / \mathrm{SD}\end{array}$ & $\begin{array}{l}63 \\
13 \\
24\end{array}$ & $\begin{array}{l}52 \\
29 \\
19\end{array}$ & 3.743 & 0.154 \\
\hline
\end{tabular}

Note: SA/A: strongly agree/agree, -: neither agree nor disagree, D/SD: disagree/strongly disagree.

${ }^{*} \mathrm{p}<0.05,{ }^{* *} \mathrm{p}<0.01,{ }^{* \star *} \mathrm{p}<0.001$

Table 7. Comparison of firms with formal and informal innovation processes - conversion stage

\begin{tabular}{|c|c|c|c|c|c|}
\hline Variable & & $\begin{array}{l}\text { Formal innovation } \\
\text { process, } n=39 \\
\%\end{array}$ & $\begin{array}{l}\text { Informal innovation } \\
\text { process, } n=134 \\
\%\end{array}$ & $\begin{array}{l}\text { Pearson } \\
\text { chi-square } \\
\text { F-value }\end{array}$ & p-value \\
\hline \multicolumn{6}{|l|}{ Selection } \\
\hline $\begin{array}{l}\text { We have tough rules for investment in new } \\
\text { projects making it hard to get ideas funded } \\
\text { in most cases }\end{array}$ & $\begin{array}{l}\mathrm{SA} / \mathrm{A} \\
- \\
\mathrm{D} / \mathrm{SD}\end{array}$ & $\begin{array}{l}20.5 \\
20.5 \\
59\end{array}$ & $\begin{array}{l}29 \\
29 \\
42\end{array}$ & 3.318 & 0.190 \\
\hline $\begin{array}{l}\text { We have a risk-taking attitude toward } \\
\text { investing in novel ideas }\end{array}$ & $\begin{array}{l}\mathrm{SA} / \mathrm{A} \\
- \\
\mathrm{D} / \mathrm{SD}\end{array}$ & $\begin{array}{l}67 \\
13 \\
20\end{array}$ & $\begin{array}{l}38 \\
30 \\
32\end{array}$ & 10.105 & $0.006^{* *}$ \\
\hline \multicolumn{6}{|l|}{ Development } \\
\hline $\begin{array}{l}\text { New-product-development projects often } \\
\text { don't finish on time }\end{array}$ & $\begin{array}{l}\mathrm{SA} / \mathrm{A} \\
- \\
\mathrm{D} / \mathrm{SD}\end{array}$ & $\begin{array}{l}46 \\
19 \\
35\end{array}$ & $\begin{array}{l}58 \\
27 \\
15\end{array}$ & 8.156 & 0.017 \\
\hline $\begin{array}{l}\text { Managers receive lots of support } \\
\text { developing new ideas }\end{array}$ & $\begin{array}{l}\mathrm{SA} / \mathrm{A} \\
- \\
\mathrm{D} / \mathrm{SD}\end{array}$ & $\begin{array}{c}79 \\
10.5 \\
10.5\end{array}$ & $\begin{array}{l}40 \\
33 \\
27\end{array}$ & 17.820 & $0.000^{\star * \star}$ \\
\hline
\end{tabular}

Note: SA/A: strongly agree/agree, -: neither agree nor disagree, D/SD: disagree/strongly disagree.

${ }^{*} p<0.05,{ }^{* *} p<0.01,{ }^{* \star *} p<0.001$ 
Diffusion stage. The IVC suggests that three factors: speed of rollout, competitor reactions, and penetration of all possible channels, customer groups and regions, are important in the diffusion stage of the IVC. It was expected that a formal innovation process would be associated with different performance on these activities. The data suggests that firms with formal innovation processes do not perform differently or better on two of the three measures (Table 8). Specifically, in terms of the speed of rollout, $51 \%$ of firms with a formal innovation process did not consider that they were slow at rolling-out new products, compared to $36 \%$ of firms with no formal process $(p=0.070)$. In terms of the speed that competitors copy new products, $23 \%$ of firms with a formal process, compared to $19 \%$ of firms with no formal process, reported that competitors are slow to copy new products $(p=0.758)$.

There is a difference between the two groups of firms in terms of penetration of all possible channels, customer groups and regions with new products. For firms with a formal innovation process, just 39\% report that they don't penetrate all possible channels, customer groups, and regions with new products, compared to $66 \%$ for firms with no formal innovation process $(p=0.005)$.

Table 8. Comparison of firms with formal and informal innovation processes - diffusion stage

\begin{tabular}{|c|c|c|c|c|c|}
\hline Variable & & $\begin{array}{c}\text { Formal innovation } \\
\text { process } n=39 \\
\%\end{array}$ & $\begin{array}{c}\text { Informal innovation } \\
\text { process } n=134 \\
\%\end{array}$ & $\begin{array}{l}\text { Pearson } \\
\text { chi-square } \\
\text { F-value }\end{array}$ & p-value \\
\hline We're slow to roll out new products & $\begin{array}{c}\mathrm{SA} / \mathrm{A} \\
- \\
\mathrm{D} / \mathrm{SD}\end{array}$ & $\begin{array}{l}23 \\
26 \\
51\end{array}$ & $\begin{array}{l}43 \\
21 \\
36\end{array}$ & 5.332 & 0.070 \\
\hline $\begin{array}{l}\text { Competitors are slow to copy our product } \\
\text { introductions }\end{array}$ & $\begin{array}{c}\text { SA / A } \\
- \\
D / S D\end{array}$ & $\begin{array}{l}23 \\
44 \\
33\end{array}$ & $\begin{array}{l}19 \\
41 \\
40\end{array}$ & 0.555 & 0.758 \\
\hline $\begin{array}{l}\text { We don't penetrate all possible channels, } \\
\text { customer groups, and regions with new } \\
\text { products }\end{array}$ & $\begin{array}{l}\mathrm{SA} / \mathrm{A} \\
- \\
\mathrm{D} / \mathrm{SD}\end{array}$ & $\begin{array}{l}39 \\
28 \\
33\end{array}$ & $\begin{array}{l}66 \\
19 \\
15\end{array}$ & 10.617 & $0.005^{\star \star}$ \\
\hline
\end{tabular}

Note: SA/A: strongly agree/agree, -: neither agree nor disagree, D/SD: disagree/strongly disagree.

${ }^{\star} p<0.05,{ }^{* *} p<0.01,{ }^{* * *} p<0.001$

\section{Discussion}

Studies of innovation and NPD practice in Ireland have focused on different endpoints, such as the number, size and industry of firms engaged in innovation (Forfás, 2012); the link between innovation and profitability (Roper and Hewitt-Dundas, 2008); Irish firms' commitment to R\&D (Kenny and Reedy, 2006); managing customer feedback on early stage ideas (Bogue and Sorenson, 2009); and managing knowledge flows to facilitate innovation (Cormican and O'Sullivan, 2004). This body of research suggests that innovation activity is concentrated in larger firms rather than in SMEs and that small firms are more operationally focussed and depend more on accidental or contingent factors to stimulate innovation (Cagliano et al. 2001; McAdam et al., 2004). It is only when firms reach significant scale (in these studies, over 200 people), that they start to focus on issues relating to strategic development and growth through innovation.

In contrast, this study focussed on how SMEs, including micro firms, manage the innovation process. Formality in the management of innovation has been associated with increased NPD performance. There is a constellation of practices, including formal innovation strategy, innovation process, metrics, teams, R\&D budget, and a dedicated team leader, that have been shown to be correlated with success in innovation (Kahn et al., 2012). This study hypothesised that a formal process would confer advantages to SMEs. The data in this paper reports that amongst a group of innovation-active Irish-owned SMEs (firms who are generating a high proportion of their revenue through NPD), $77 \%$ of firms do not use a formal innovation process. This is consistent with Turner et al.'s (2010) conclusion that many Irish firms do not employ any form of formal project 
management when managing innovation, despite using it for operations management. While the data in this study shows that firms with a formal innovation process report higher revenues from new products $(47 \%$ compared to $35 \%)$, the difference is not statistically significant at the $p<0.01$ level $(p=0.029)$. Firms without a formal innovation process were on average generating one-third of revenues from products and services launched in the prior three years. That is, irrespective of the formality of the innovation process, firms can deliver high levels of innovation.

Given the emphasis of recent research on stages within the innovation process, this study explored if a formal innovation process might be associated with better performance at various stages of the innovation process. On one overall measure of innovation that might transcend all three components of the IVC, novelty of innovations, there is a difference between firms with and without a formal innovation process. $56 \%$ of firms with a formal innovation process, compared to $24 \%$ of firms without a formal innovation process, reported that their new products have been the first of their kind to market $(p=0.000)$. Being first to the market might suggest a higher level of originality in ideas (idea generation stage), a more risk-taking attitude in prioritising projects (conversion stage), and a capacity to execute and get to the market before competitors (diffusion stage). It might be that firms with a formal innovation process might have a more purposeful and strategic focus and commitment to innovation. Being first to the market can have considerable advantages and is not something normally associated with Irish-owned SMEs according to the CIS data (Forfás, 2012).

However, the firms do not differ systematically in terms of the three stages of the IVC. Firms with formal processes only performed better on 3 of the 13 measures (at $p<0.01$ ). A formal innovation process is associated with a risk-taking attitude towards investing in new ideas (conversion stage) and with managers receiving support for developing new ideas (conversion stage), and with penetration of more channels, customer groups, and regions (diffusion stage).

Why might the absence of formal innovation processes not matter much in SMEs? There are a number of reasons why SMEs might be able to deliver on innovation outcomes without formal processes. First, extant research has highlighted how smaller firms are characterised by flexible organisational structures (Qian and $\mathrm{Li}, 2003$ ) and less bureaucracy and systemised approaches to decision making (Turner et al., 2010). Recent research has suggested that informal processes, such as processes of effectuation and improvisation, are effective in the context of new and small firms (Baker et al., 2003; Sarasvathy 2008; Dew et al., 2009).

Second, the firms in this study are all innovation-active. It may be that a longer time horizon is required to understand the benefits of a formal innovation process. For example, formality might assist firms not yet innovation-active to become innovation-active, as it provides a way of managing what might be a new process to the firm. Similarly, longer time periods might show that formality in the innovation process might benefit firms as they seek to sustain innovation over longer time periods or as they seek to maintain innovation during periods of managerial or organisational transitions that are common in SMEs as they grow (Phelps et al., 2007).

Third, SMEs characterised by high growth rates are also characterised by innovation (NESTA, 2011; Forfás, 2014). The innovation index used in this study may have attracted a disproportionately high number of high-growth SMEs. Using Irish CIS data, Forfás reported that up to $93 \%$ of Irish high-growth firms (HGFs) are innovation active (2014: 14), with approximately half of the HGFs involved in innovation having introduced goods or services that were 'new to the market'. All of the firms in this study are innovation active, and $46 \%$ of the firms reported that their products/services were the first of the kind to the market. In contrast, in the CIS data, just $60 \%$ of firms are innovation active and only $16 \%$ reported that their innovation is the first of the kind to the market (Forfás, 2012: 32). If the firms in this study are characterised by high growth, this may explain the absence of formal systems. Research on HGFs shows that the development of structures, systems and processes follow rather than lead periods of high growth (Greiner, 1972).

Fourth, small firms (which make up the bulk of the SME category) generally pursue a limited number of innovation projects at any given time, often just one, because of their limited resources (Laforet, 2008). Consequently, their familiarity, understanding and skill in product innovation are often limited:

'With no need to manage a portfolio of innovation projects at the same time and thus no pressure to select among projects to allocate resources, small firms have neither opportunity nor incentive to routinize innovation or formalize NPD stage-gates or selection procedures, as big firms do.' (Berends et al., 2014: 618) 


\section{Conclusions}

This study makes a number of contributions. First, in terms of the research on innovation in Irish SMEs, this study contributes to the understanding of innovation processes in Irish-owned SMEs. While existing research has reported on levels of innovation activity in Irish SMEs and, to a lesser extent, on the extent of openness and collaboration in innovation in SMEs, this study focussed on innovation processes within innovation-active SMEs. The study highlights that SMEs can deliver high levels of innovation outputs despite relatively few adopting formal innovation processes. Specifically, it demonstrates that micro and small firms (the former are excluded from the CIS data) can have high levels of innovation outputs. However, formality in the innovation process is associated with more novel innovations.

Second, this study contributes to the emerging literature that has emphasised the effectiveness of informal processes. The study shows that in SMEs informal processes confer many of the advantages of formal processes in the management of innovation. Our findings suggest that the standard of best practices in innovation management (e.g. Kahn etal., 2006) needs to acknowledge and accommodate the differences between large firms and small firms. When it comes to innovation, SMEs are not merely miniaturised large firms; they have special characteristics and constraints. What is traditionally seen and promoted as best practice (e.g. Cooper and Kleinschmidt, 1995; Kahn etal., 2006), has usually come from large-firm studies and is largely agnostic to the conditions and limitations that prevail in SMEs. The very definition of SME's according to Ghobadian and Gallear (1997), assumes that their planning is simple, their reporting informal, their decision-making idealistic, and their degree of specialization low.

Third, the study developed an innovation audit tool that is based on the IVC that might help managers identify 'gaps' in performance and provide 'blue prints' of best practice (Chiesa et al., 1996). The innovation audit tool developed in this study exploits an understanding of the innovation process that emphases the three constituent components of the innovation value chain and overlays them with some known factors associated with best practice.

An implication of this study for managers is that high levels of innovation outcomes can be achieved through informal innovation processes. As managers know, managing innovation is not easy. Reflecting these difficulties, various authors have used colourful metaphors and language to characterise the process of managing innovation, for example, 'Grabbing Lightning' (Correlli-O'Connor, 2008) and 'Innovation Leaders Should be Controlled Schizophrenics' (Buijs, 2007). While there is much emphasis in the management literature on the benefits of formalising management processes, including those associated with innovation, in some SMEs the lack of a formal innovation process may not matter. The challenge for managers is to tailor innovation management processes to the firm size, growth objectives, resources and organisational and competitive context.

Overall, it appears that while the adoption of a formal process may not confer benefits in terms of revenue gains from innovation (in the prior three years), a formal innovation process may be an important step in developing an innovation capability. A formal innovation process correlates with best practices in innovation in larger firms, such as having an innovation strategy, R\&D budgets, dedicated team leaders and cross-functional teams. For that reason alone, managers may consider it worthwhile putting in place a dedicated process that helps facilitate innovation. 
Akroyd, C., Narayan, S. and Sridharan, V. (2009). 'The use of control systems in new product development innovation: Advancing the "help or hinder" Debate'. IUP Journal of Knowledge Management, 7(5), 70-90.

Amabile, T. (1998). 'How to kill creativity'. Harvard Business Review, 76, 76-87.

Audretsch, D., van der Horst, R., Kwaak, T. and Thurik, R. (2009). First Section of the Annual Report on EU Small and Medium-sized Enterprises, European Commission, Directorate General Enterprise and Industry, Zoetermeer.

Baker, T., Miner, A. and Eesley, D. (2003). 'Improvising firms: Bricolage, account giving and improvisational competencies in the founding process'. Research Policy, 32, 255.

Barclay, I. and Porter, K. (2005). 'Facilitating innovation across SME networks'. International Journal of Entrepreneurship and Innovation Management, 5(1), 1-1.

Barczak, G., Griffin, A. and Kahn, K. (2009). 'Perspective: Trends and drivers of success in NPD practices: Results of the 2003 PDMA best practices study'. Journal of Product Innovation Management, 26(1), 3-23.

Bart, C. (1991). 'Controlling new products in large diversified firms: A presidential perspective'. Journal of Product Innovation Management, 8(1), 4-17.

Berends, H., Jelinek, M., Reymen, I. and Stultiëns, R. (2014). 'Product innovation processes in small firms: Combining entrepreneurial effectuation and managerial causation'. Journal of Product Innovation Management, 31, 616-635.

Bessant, J., Lamming, R., Noke, H. and Phillips, W. (2005). 'Managing innovation beyond the steady state'. Technovation, 25, 1366-1376.

Bogue, J. and Sorenson, D. (2009). 'Managing customer knowledge during the concept development stage of the new food product development process'. Journal Of International Food and Agribusiness Marketing, 21(2/3), 149-165.

Bonner, J. (2005). 'The influence of formal controls on customer interactivity in new product development'. Industrial Marketing Management, 34, 63-69.

Brophey, G., Baregheh, A. and Hemsworth, D. (2013). 'Innovation process, decision-making, perceived risks and metrics: A dynamics test'. International Journal of Innovation Management, 17(3), 1-22.

Brown, S. and Eisenhardt, K. (1995). 'Product development: Past research, present findings, and future directions'. Academy of Management Review, 20, 343-378.

Buijs, J. (2007). 'Innovation leaders should be controlled schizophrenics'. Creativity and Innovation Management, 16, 203-210.

Burns, T. and Stalker, G. (1961). The Management of Innovation, 1st edn, Oxford: Oxford University Press.

Cagliano, R., Blackmon, K. and Voss. C. (2001). 'Small firms under the microscope: International differences in production/operations management practices and performance'. Integrated Manufacturing Systems, $12,469-482$.

Cefis, E. (2003). 'Is there Persistence in Innovative Activities?'. International Journal of Industrial Organization, 21, 489.

Cefis, E. and Ciccarelli, M. (2005). 'Profit differentials and innovation'. Economics Of Innovation \& New Technology, 14, 43-61

Central Statistics Office (CSO) (2013). Business in Ireland 2011, Dublin: Government Publications.

Chandler, A., Hagström, P. and Sölvell, O. (1998). The Dynamic Firm. The Role of Technology, Strategy, Organisation and Regions, Oxford: Oxford University Press.

Chiesa, V., Coughian, P. and Voss, C. (1996). 'Development of a technical innovation audit'. Journal of Product Innovation Management, 13, 105-136.

Cooper, R. (2001). Winning at New Products; Accelerating the Process from Idea to Launch, New York: Perseus Books.

Cooper, R. and Edgett, S. (2008). 'Maximizing productivity in product innovation'. Research Technology Management, 51(2), 47-58.

Cooper, R. and Kleinschmidt, E. (2007). 'Winning businesses in product development: The critical success factors'. Research Technology Management, 50(3), 52-66.

Cormican, K. and O'Sullivan, D. (2004). 'Auditing best practice for effective product innovation management'. Technovation, 24, 819-829.

Correlli-O'Connor, G. (2008). Grabbing Lightening Building a Capability for Breakthrough Innovation, San Francisco: John Wiley and Sons.

Davila, A., Foster, G. and Li, M. (2009). 'Reasons for management control systems adoption: Insights from product development systems choice by earlystage entrepreneurial companies'. Accounting, Organizations \& Society, 34, 322-347. 
Dew, N., Read, S., Sarasvathy, S.D. and Wiltbank, R. (2009). 'Effectual versus predictive logics in entrepreneurial decision-making: Differences between experts and novices'. Journal of Business Venturing, 24, 287-309.

Doran, J., Jordan, D. and O'Leary, E. (2012). 'The effects of the frequency of spatially proximate and distant interaction on innovation by Irish SMEs'. Entrepreneurship and Regional Development, 24, 705-727.

Drucker, P. (1985). Innovation and Entrepreneurship. Practice and Principles, New York: Harper Business.

European Union (2014). Innovation Union Scorecard 2014, European Union Publications Office

Forfás (2009). Sharing our Future: Ireland 2025 - Strategic Requirements for Enterprise Development, Dublin: Irish Government.

Forfás (2012). Community Innovation Survey 2008-2010, Dublin: Irish Government.

Forfás (2014). Innovation in Agency-Supported High Growth Firms in Ireland, Dublin: Irish Government.

Ganotakis, P. and Love, J. (2012). 'The innovation value chain in new technology-based firms: Evidence from the U.K'. Journal of Product Innovation Management, 29, 839-860.

Geroski, P., Machin, S. and Walters, C. (1997). 'Corporate growth and profitability'. Journal of Industrial Economics, 45, 171.

Ghobadian, A. and Gallear, D. (1997). 'TQM and organisation size'. International Journal of Operations and Production Management, 17, 121-163.

Greiner, L. (1972). 'Evolution and revolution as organizations grow'. Harvard Business Review, 50, 37-46.

Griffin, A. (1997). 'PDMA research on new product development practices: Updating trends and benchmarking best practices'. Journal of Product Innovation Management, 14, 429-458.

Hansen, M. and Birkinshaw, J. (2007). 'The innovation value chain'. Harvard Business Review, 85, 121-130.

Harris, R. and Trainor, M. (1995). 'Innovations and R and D in Northern Ireland manufacturing: A Schumpeterian approach'. Regional Studies, 29, 593-604.

Healy, B., Ledwith, A. and O'Dwyer, M. (2014). 'Perceptions of product advantage, NPD and organisational performance'. Journal of Small Business and Enterprise Development, 21(1), 49-68.

Hewitt-Dundas, N. (2006). 'Resource and capability constraints to innovation in small and large plants'. Small Business Economics, 26, 257-277.

Hewitt-Dundas, N. and Roper, S. (2008). 'Ireland's innovation performance: 1991 to 2005'. Quarterly Economic Commentary, 45-71.
Hoffman, K., Parejo, M., Bessant, J. and Perren, L. (1998). 'Small firms, R\&D, technology and innovation in the UK: A literature review'. Technovation, 18(1), 39.

Hutchins, N. and Muller, A. (2012). 'Beyond stagegate: Restoring learning and adaptability to commercialization'. Strategy and Leadership, 40(3), 30-35.

Jones, T., McCormick, D. and Dewing, C. (2012). Growth Champions - the Battle for Sustained Innovation Leadership, Chichester: John Wiley and Sons.

Jordan, D. and O'Leary, E. (2011). 'The role of external interaction for innovation in Irish hightechnology businesses'. International Journal of Entrepreneurship and Innovation, 12, 248-256.

Kahn, K., Barczak, G. and Moss, R. (2006). 'Perspective: Establishing an NPD best practices framework'. Journal of Product Innovation Management, 23(2), 106-116.

Kahn, K., Barczak, G., Nicholas, J., Ledwith, A. and Perks, H. (2012). 'An examination of new product development best practice'. Journal of Product Innovation Management, 29(2), 180-192.

Kanter, R. (1983). The Change Masters: Innovation Productivity in the American Corporation, New York: Simon and Schuster.

Kenny, B. and Reedy, E. (2006). 'The impact of organisational culture factors on innovation levels in SMEs: An empirical investigation'. Irish Journal of Management, 27(2), 119-142.

Laforet, S. (2008). 'Size, strategic, and market orientation effects on innovation'. Journal of Business Research, 61(7), 753-764.

Lee, C., Lee, K. and Pennings, J. (2001). 'Internal capabilities, external networks, and performance: A study on technology-based ventures'. Strategic Management Journal, 22(6), 615.

Loewe, P. and Chen, G. (2007). 'Changing your company's approach to innovation'. Strategy and Leadership, 35(6), 18-26.

Love, J.H., Ashcroft, B. and Dunlop, S. (1996). 'Corporate structure, ownership and the likelihood of innovation'. Applied Economics, 28, 737-746.

Malerba, F. and Orsenigo, L. (1997). 'Persistence of innovative activities, sectoral patterns of innovation and international technological specialisation'. International Journal of Industrial Organization, 15, 801.

March, J. (1991). 'Exploration and exploitation in organizational learning'. Organization Science, 2(1), 71-87.

March-Chordà, I., Gunasekaran, A. and Lloria-Aramburo, B. (2002). 'Product development process in Spanish SMEs: An empirical research'. Technovation, 22, 301. 
McAdam, R., Reid, R. and Gibson, D. (2004). 'Innovation and organisational size in Irish SMEs: An empirical study'. International Journal of Innovation Management, 8, 147-165.

Meyer M, Anzani M, and Walsh G. (2005). 'Innovation and enterprise growth'. Research Technology Management, 48(4), 34-44.

NESTA, (2011). Vital Growth: The Importance of High Growth Businesses to the Recovery, London.

Nelson, R. and Winter, S. (1982). 'The Schumpeterian trade-off revisited'. American Economic Review, 72(1), 114.

O'Connor, G. (2009). 'Sustaining breakthrough innovation'. Research Technology Management, 52(3), 12-14.

O'Connor, G. and Ayers, A. (2005). 'Building a radical innovation competency'. Research Technology Management, 48, 23-31.

OECD (2014). Financing SMEs and Entrepreneurs 2014, Organisation for Economic Co-operation and Development.

Owens, J. (2007). 'Why do some UK SMEs still find the implementation of a new product development process problematical? An exploratory investigation'. Management Decision, 45, 235-251.

Page, A. (1993). 'Assessing new product development practices and performance: Establishing crucial norms'. Journal of Product Innovation Management, 10, 273-290.

Phelps, R., Adams, R. and Bessant, J. (2007). 'Life cycles of growing organizations: A review with implications for knowledge and learning'. International Journal of Management Reviews, 9(1), 1-30.

Qian, G. and Li, L. (2003). 'Profitability of small- and medium-sized enterprises in high-tech industries: The case of the biotechnology industry'. Strategic Management Journal, 24, 881-887.

Radnor, Z. and Noke, H. (2006). 'Development of an audit tool for product innovation: The innovation compass'. International Journal of Innovation Management, 10(1), 1-18.

Roper, S., Du, J. and Love, J. (2008). 'Modelling the innovation value chain'. Research Policy, 37, 961977.

Roper, S. and Hewitt-Dundas, N. (2008). 'Innovation persistence: Survey and case-study evidence'. Research Policy, 37(1), 149-162.

Rosenbusch, N., Brinckmann, J. and Bausch, A. (2011). 'Is innovation always beneficial? A meta-analysis of the relationship between innovation and performance in SMEs'. Journal of Business Venturing, 26, 441-457.
Sarasvathy, S. (2008). Effectuation: Elements of Entrepreneurial Expertise, Cheltenham: Edward Elgar.

Sawhney, M., Wolcott, R. and Arroniz, I. (2006). 'The 12 different ways for companies to innovate'. MIT Sloan Management Review, 47(3), 75-81.

Schumpeter, J. (1939). Business Cycles, McGraw Hill.

Thompson, V. (1965). 'Bureaucracy and innovation'. Administrative Science Quarterly, 10(1), 1-20.

Tidd, J. and Bessant, J. (2009). Managing Innovation Integrating Technological, Market and Organizational Change, West Sussex: John Wiley and Sons.

Tidd, J. and Bodley, K. (2002). 'The influence of project novelty on the new product development process'. $R \& D$ Management, 32(2), 127.

Tomlinson, P. (2011). 'Strong ties, substantive embeddedness and innovation: Exploring differences in the innovative performance of small and medium-sized firms in UK manufacturing'. Knowledge and Process Management, 18(2), 95108.

Turner, R., Ledwith, A. and Kelly, J. (2010). 'Project management in small to medium-sized enterprises: Matching processes to the nature of the firm'. International Journal of Project Management, 28, 744-755.

Tushman, M. (1997). 'Winning through innovation'. Strategy and Leadership, 25(4), 14.

Tyng-Ruu Lin, G., Yo-Hsing C. and Yung-Chi S. (2010). 'Innovation policy analysis and learning: Comparing Ireland and Taiwan'. Entrepreneurship and Regional Development, 22, 731-762.

Van de Vrande, V., de Jong, J., Vanhaverbeke, W. and de Rochemont, M. (2009). 'Open innovation in SMEs: Trends, motives and management challenges'. Technovation, 29, 423-437.

Veryzer, J. (1998). 'Discontinuous innovation and the new product development process'. Journal of Product Innovation Management, 15, 304-321.

Veugelers, R. (2008). 'The role of SMEs in innovation in the EU: A case for policy intervention?'. Review of Business and Economics, 53, 239.

Vuola, O. and Hameri, A. (2006). 'Mutually benefiting joint innovation process between industry and bigscience'. Technovation, 26(1), 3-12.

Yang, C. (2012). 'Assessing the moderating effect of innovation capability on the relationship between logistics service capability and firm performance for ocean freight forwarders'. International Journal of Logistics: Research and Applications, 15(1), 53-69. 